\title{
Primary Malignant Bones Cancers in Cote d'Ivoire: Epidemiological and Histopathological Aspects
}

\section{Kone Samba1 ${ }^{*}$, J. N'dah Kouame², R. Kouakou Konan³ , A. Ngandjeu Nawé4, Doukoure Brahima², Bana Abdoulaye1, Eti Edmond4 ${ }^{4}$ Agoh Serge ${ }^{1}$}

\author{
${ }^{1}$ Service de Traumatologie-CHU de Cocody, Abidjan, Cote d'Ivoire \\ ${ }^{2}$ Service d'Anatomie et Cytologie Pathologiques-CHU de Cocody, Abidjan, Cote d'Ivoire \\ ${ }^{3}$ Service de Stomatologie-CHU de Cocody, Abidjan, Cote d'Ivoire \\ ${ }^{4}$ Service de Rhumatologie-CHU de Cocody, Abidjan, Cote d'Ivoire \\ Email: *k.samba06@gmail.com
}

How to cite this paper: Samba, K., Kouame, J.N., Konan, R.K., Nawé, A.N., Brahima, D., Abdoulaye, B., Edmond, E. and Serge, A. (2018) Primary Malignant Bones Cancers in Cote d'Ivoire: Epidemiological and Histopathological Aspects. Open Journal of Pathology, 8, 51-59. https://doi.org/10.4236/ojpathology.2018.82006

Received: February 7, 2018

Accepted: March 16, 2018

Published: March 19, 2018

Copyright $\odot 2018$ by authors and Scientific Research Publishing Inc. This work is licensed under the Creative Commons Attribution International License (CC BY 4.0).

http://creativecommons.org/licenses/by/4.0/

\section{(c) (†) Open Access}

\begin{abstract}
Primary bones cancers are rare and ubiquitous malignant tumors. Aim: Our study aimed was to describe the epidemiological and histopathological aspects of primary malignant bone cancers in Ivory Coast. Material and method: This is a retrospective and descriptive study of primary malignant bone cancers diagnosed over the period 1990 to 2013 (24 years). The studied parameters were: epidemiological aspects (frequency, age, sex, topography) and histological aspects. Results: Over the study period, primary malignant bone cancers accounted for $1.93 \%(n=228)$ of cancers. The average age was 27.02 years with extremes of 2 and 85 years. The sex ratio was 1.65 . They were in the skull and maxilla in $43.9 \%(\mathrm{n}=105)$, lower limbs $(23.8 \%)$, spine and ribs (19.8\%), pelvis (5.3\%) and upper limbs (2.3\%). The clinic was dominated by pain and alteration of general state. Radiology was variable depending on the histological type. In children, primary malignant bone cancers were found in the maxillary $(77.9 \%)$ and the lower limb (15.8\%). Burkitt's lymphomas represented $36.4 \%(n=66)$ of the histological types followed by $22.4 \%$ osteosarcomas $(n=51)$. In adults at histology, sarcomas were the most common (10\%), followed by cancers of the hematopoietic and lymphatic organs $(8.09 \%)$. Conclusion: Primary malignant bone cancers are rare in Ivory Coast. They most often affect male children with maxillofacial involvement and predominant lower extremity. Burkitt's lymphoma and osteosarcoma are the often diagnosed histological types.
\end{abstract}

\section{Keywords}

Cancers, Bones, Epidemiology, Histopathology, Cote d'Ivoire 


\section{Introduction}

Primary bones cancers are relatively rare malignant tumors, mainly affecting the big child, the adolescent and the young adult. They represent about $0.2 \%$ of adult cancers and $5 \%$ of childhood cancers [1] [2].

Their diagnosis is usually based on anatomopathological examination correlated with clinical and radiographic data. These cancers prognosis is often fatal in most countries. Current multidisciplinary therapeutic strategies have improved the prognosis over the last twenty years in developed countries [1] [3].

In Africa, and particularly in Ivory Coast, the health priority remains endemic and epidemic diseases (yellow fever, malaria and today HIV infection). Yet for decades some authors [4] [5] have issued alerts on the extent of the general cancer pathology in our country.

In the West [6], malignant bone tumors are dominated by multiple myeloma. Among malignant bone tumors Daboiko, Nzué [7] [8] point out that bone metastases seem more common than primitive malignant bone tumors. The true incidence of malignant bone tumors primitive seems to be poorly known in Côte d'Ivoire because no studies have been reported so in recent years.

In carrying out this study, we set ourselves the objective of contributing to the optimal management of primary bone cancers in Côte d'Ivoire by describing their epidemiological and histopathological aspects.

In carrying out this study, we had an objective to contribute to the optimal management of primary malignant bone cancers in Cote d'Ivoire by describing their epidemiological and histopathological aspects.

\section{Material and Method}

This is a retrospective and descriptive study carried out in the pathological anatomy laboratories of the Abidjan Universities Hospitals (UHs) in collaboration with three other departments (traumatology, maxillofacial stomatology and rheumatology). This was a retrospective and descriptive study on histologically confirmed cancers and identified from the different registers of pathological anatomy laboratories of the three Abidjan UHs and PISAM. The study period was 24 years (January 1990 to December 2013).

It dealt with the primary cancers of the bones histologically diagnosed and recorded from the logbooks of these services. The study period was 24 years (January 1990 to December 2013).

From the registers survey form has been pre-established for the datacollection. The following information was systematically collected: the epidemiological aspect, the clinical and radiological characteristics, the sample (nature, site, hospital and department requesting the examination) and the histological diagnosis.

The diagnosis of primary bone tumor was made from clinical, radiological, biological and histological findings were tained only primary malignant tumor records with histological confirmation regardless of age, sex and bone location.

Benigntumors and secondary bone localization of osteophyle cancers (bone 
metastases) have been excluded the samples were previously fixed with $10 \%$ formalin and decalcified according to the usual protocol. Then, they were subjected to standard paraffin embedding, microtome cutting, and Hematoxylin-Eosin staining techniques. In some cases, the immunohistochemistry technique was performed in some wards in France or in North Africa to refine the diagnosis (lymphomas, Ewing's sarcoma and rhabdomyosarcoma). The diagnosis of various malignant tumors and their classifications by apparatus are in accordance with the International Statistical Classification of Tumors proposed by WHO in 1993 (ICD-10). Data processing was done using the SPSS version 2013 software. the parameters taken into account were sociodemographic, clinical, radiological, and histological diagnosis.

\section{Results}

\subsection{Frequency}

During the study period, we recorded 272 malignant bone tumors cases, of which 228 were primitive.

Malignant bone tumors represented $1.93 \%$ of all cancers. Among the bone cancers identified, $83.8 \%$ were primary malignant cancers and $16.1 \%$ were bone metastases.

The annualfrequencywas 9.5 cases with a frequencypeak in 1995 ( $\mathrm{n}=19$ cases).

\subsection{Age and Sex}

Male subjects represented $62.3 \%$ of cases $(n=142)$, then a sex ratio of 1.65 . The patients' average age was 27.02 years with extremes of 2 years and 86 years. The 0 to 14 age group was the most affected with a rate of $46.1 \%$ of cases $(n=105)$. Figure 1 shows data for different age groups. In $91.66 \%$ of cases the patients are

\section{Effective}

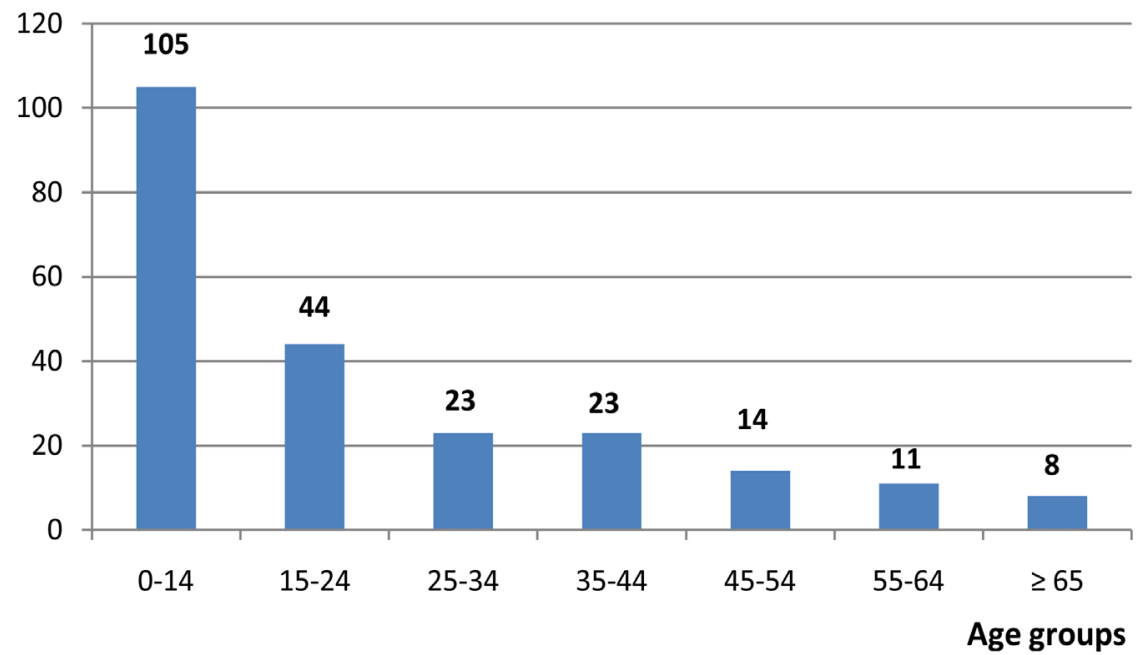

Figure 1. Distribution of primary bone cancers by age group. 
under 55 years old.

\subsection{Topography}

The primary malignant bone cancers different localizations were: maxillary and skull $(48.7 \%, \mathrm{n}=111)$ lower limbs $(24.1 \%, \mathrm{n}=55)$, spine and ribs $(19.7 \%, \mathrm{n}=$ $45)$, pelvis $(5.3 \%, \mathrm{n}=12)$ and upper limbs $(2.2 \%, \mathrm{n}=5)$. Figure 2 shows data for different age groups.

In the lower limb these tumors are around the knee in $92.72 \%$ of cases.

\subsection{Clinical and Radiological Aspect}

The clinic was dominated by pain and alteration of the general state. Radiology quite variable depending on the histological type.

\subsection{Histological Type}

Burkitt's lymphoma was the most common histological type with $39 \%$ of cases $(\mathrm{n}=89)$ followed by osteosarcoma (22.4\%), malignant non-Hodgkin's lymphoma (11\%) and chondrosarcoma (7.5\%).

\subsubsection{Correlation of Histological Type According by Topography} Burkitt's lymphomas were present in $91 \%$ cases $(n=81)$ on the maxillary and skull. Osteosarcomas were localized in the lower limbs in $76.5 \%$ of cases $(\mathrm{n}=$ 39).

The distribution of the different histological types according to the topography is reported in Table 1.

\subsubsection{Correlation of Histological Type According to Age Group}

Burkitt's lymphomas were most often diagnosed in children (0 - 14 years) at a rate of $31.2 \%(n=71)$. Osteosarcomas were observed in the age group $15-24$ years (33.3\% of cases).

Non-Hodgkin's malignant lymphomas without other indications and osteosarcomas were common in the age groups 0 - 14 years and 15 - 24 years, respectively, with proportions of $36 \%$ and $47 \%$ of cases.

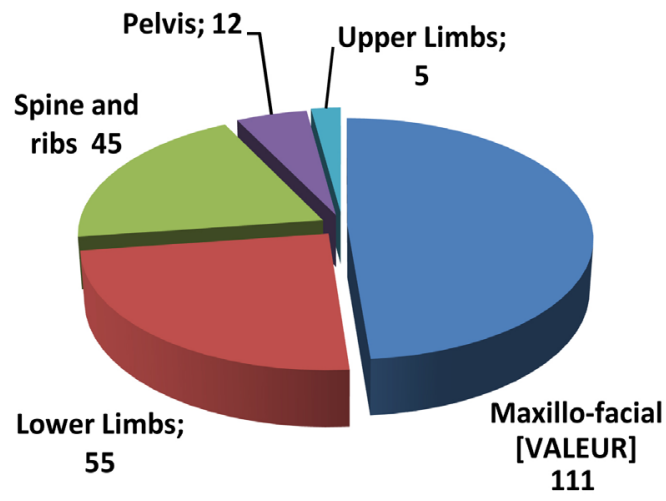

Figure 2. Distribution of primary bones cancers localizations. 
Table 1. Correlation of histological types by topography.

\begin{tabular}{|c|c|c|c|c|c|c|c|}
\hline \multirow{3}{*}{ Histological types } & \multicolumn{5}{|c|}{ Topography } & \multirow{3}{*}{ TotaI } & \multirow{3}{*}{$\%$} \\
\hline & \multirow{2}{*}{\multicolumn{2}{|c|}{ Maxillo-facial Lowerlimbs }} & \multirow{2}{*}{$\begin{array}{l}\text { Spine } \\
\text { and } \\
\text { ribs }\end{array}$} & \multirow[b]{2}{*}{ Pelvis } & \multirow[b]{2}{*}{ Upperlimbs } & & \\
\hline & & & & & & & \\
\hline Burkitt'slymphoma & 81 & 1 & 7 & 0 & 0 & 89 & 39.0 \\
\hline Osteosarcoma & 5 & 39 & 4 & 2 & 1 & 51 & 22.4 \\
\hline NHL with large cell & 13 & 0 & 8 & 3 & 1 & 25 & 11.0 \\
\hline Chondrosarcoma & 5 & 2 & 8 & 2 & 0 & 17 & 7.5 \\
\hline Rhabdomyosarcoma & 1 & 4 & 1 & 1 & 0 & 7 & 3.1 \\
\hline Multiplemyeloma & 1 & 0 & 12 & 1 & 0 & 14 & 6.1 \\
\hline Plasmocytoma & 1 & 0 & 4 & 1 & 0 & 6 & 2.6 \\
\hline Ewing'ssarcoma & 0 & 3 & 0 & 0 & 1 & 4 & 1.8 \\
\hline Fibrosarcoma & 0 & 2 & 0 & 1 & 1 & 4 & 1.8 \\
\hline NHL withsmollcell... & 1 & 0 & 1 & 1 & 0 & 3 & 1.3 \\
\hline Indifferenciatesarcoma & 1 & 1 & 0 & 0 & 1 & 3 & 1.3 \\
\hline Synovialosarcoma & 0 & 2 & 0 & 0 & 0 & 2 & 0.9 \\
\hline Neuroblastoma & 1 & 1 & 0 & 0 & 0 & 2 & 0.9 \\
\hline Total & 111 & 55 & 45 & 12 & 5 & 228 & 100 \\
\hline
\end{tabular}

Table 2 reports the correlation between histological types and age groups.

\section{Discussion}

Our present study aim was to describe the epidemiological and histopathological aspects of primary bone cancers in Ivory Coast by analyzing the medical records of our patients treated for primary malignant bone tumors (PMBT).

The limit of our study is its retrospective nature; however, although the results do not provide national statistics, they provide a basis for future studies on bone tumors. Our study is distinguished by the large sample size which gives this study some value to comment on.

\subsection{Epidemiology}

The incidence of PMBT is very variable from one country to another or from one continent to another [9].

If in Europe and America developed countries it is high, in Asia it seems weak [10] as was the case in our study.

Daboiko et al. [8] in Ivory Coast and Omololu [11] in Nigeria also point out this low incidence compared to malignant bone tumors secondary. On the other hand Bahebeck et al. [12] reported a high frequency of PMBT (45\%) in his series in Cameroon. In our series the actual frequency can not be accurately estimated because of the lack of national registry on bone tumors.

The average age of 27.02 reported in this work is comparable to those of bana et al. [9] and ibrahima [13]. 
Table 2. Correlation between histological types and age groups.

\begin{tabular}{|c|c|c|c|c|c|c|c|c|c|}
\hline \multirow{2}{*}{ Histological type } & \multicolumn{7}{|c|}{ Age groups (year) } & \multirow{2}{*}{ TotaI } & \multirow{2}{*}{$\%$} \\
\hline & $0-14$ & $15-24$ & $25-34$ & $35-444$ & $45-54$ & $55-64$ & $\leq 65$ & & \\
\hline Burkitt'slymphoma & 71 & 12 & 5 & 1 & 0 & 0 & 0 & 89 & 39.0 \\
\hline Osteosarcoma & 16 & 17 & 8 & 5 & 1 & 2 & 2 & 51 & 22.4 \\
\hline NHL withlarge cell & 9 & 3 & 2 & 4 & 2 & 3 & 2 & 25 & 11.0 \\
\hline Chondrosarcoma & 2 & 8 & 3 & 1 & 2 & 1 & 0 & 17 & 7.5 \\
\hline Rhabdomyosarcoma & 2 & 3 & 1 & 1 & 0 & 0 & 0 & 7 & 3.1 \\
\hline Multiplemyeloma & 0 & 0 & 0 & 6 & 5 & 2 & 1 & 14 & 6.1 \\
\hline Plasmocytoma & 0 & 0 & 1 & 3 & 1 & 1 & 0 & 6 & 2.6 \\
\hline Ewing'ssarcoma & 1 & 1 & 1 & 1 & 0 & 0 & 0 & 4 & 1.8 \\
\hline Fibrosarcoma & 0 & 0 & 0 & 1 & 1 & 1 & 1 & 4 & 1.8 \\
\hline NHL withsmollcell... & 0 & 0 & 0 & 0 & 0 & 1 & 2 & 3 & 1.3 \\
\hline Indifferenciatedsarcoma & 2 & 0 & 1 & 0 & 0 & 0 & 0 & 3 & 1.3 \\
\hline Synovialosarcoma & 0 & 0 & 1 & 0 & 1 & 0 & 0 & 2 & 0.9 \\
\hline Neuroblastoma & 2 & 0 & 0 & 0 & 0 & 0 & 0 & 2 & 0.9 \\
\hline Ameloblasticcarcinoma & 0 & 0 & 0 & 0 & 1 & 0 & 0 & 1 & 0.4 \\
\hline Total & 105 & 44 & 23 & 23 & 14 & 11 & 8 & 228 & 100 \\
\hline
\end{tabular}

NHL: Non-Hodgkin's lymphoma.

All [9] [12] [14] agree to recognize as Triffaud [15] that the affection occurs in $50 \%$ of cases during the 2 nd decade of life and in $60 \%$ of cases in the man. The male predominance found in our series and that of Effi et al. [16] corroborates this statement.

We noticed that only $8.34 \%$ of PMBT occur after 55 years. This finding converges with the results of some authors who emphasize instead a clear predominance of bone metastases after 50 years [12] [17] [18].

It follows that in children, adolescents, and young adults, a malignant bone tumor is often primitive [13] [17] [19]. In fact $91.66 \%$ of patients were under 55 years old in our series.

\subsection{Histology}

On 228 bone tumor cases collected in our study, primary bone malignant cancers were dominated by burkitt's lymphoma (89 cases, 39\%) and osteosarcoma (51 cases, 22.4\%), non Hodgkinsmalignant lymphomas without further indication (28 cases, $12.3 \%$ ) and chondrosarcomas (17 cases, $7.5 \%$ ).

Osteosarcoma is the second leading cause of PMBT with $22.4 \%$ of cases after Burkitt's lymphoma. These results contrast with those of Togo where kakpovi et al. [17] found 34 myeloma cases and 9 osteosarcoma cases in 166 primary malignant bone tumors (PMBT) cases.

In Mexico, Weber et al. [20] found a higher frequency of osteosarcoma on Ewing tumors and chondrosarcoma In Mexico, Baena-Ocampo et al. [21] found in their series of malignant bone tumors in order of decreasing frequency, os- 
teosarcoma (46.6\%), chondrosarcoma (8.7\%) and multiple myeloma bones (8.1\%). On the contrary, in India, over 5 years, Yeole et al. [22] found in terms of frequency related to primary malignant tumors a predominance of Ewing's sarcoma in front of chondrosarcoma and osteosarcoma. In Nigeria, Abdulkareem et al. [23] Lagos found a clear predominance of osteosarcoma in the 77 cases of bone tumors collected. These results confirm the variable incidence of osteosarcoma according to the type of population.

Following literature [19], osteosarcoma and Ewing's tumor constitute about $90 \%$ of all malignant bone tumors in children. Our results are different because they are Burkitt's lymphoma and osteosarcoma, which predominate respectively $67.61 \%$ and $15.23 \%$ of cases in children.

For Segbena et al. [24] Burkitt's lymphoma accounts for $73.7 \%$ of malignant lymphomas and $45.9 \%$ of childhood cancers.

In the literature, Burkitt's lymphoma is likely to be the first malignant tumor of children in sub-Saharan Africa [16] [24] [25].

This preferential predilection in children is explained by the contributing factors described by several authors: precarious socio-economic conditions (malnutrition, poor hygienic conditions, promiscuity) geographical location, acquired immune deficiency states (infections with Epstein's virus)-Barr, HIV infection) or hereditary [26] [27] [28].

In our series in adults with histology, sarcomas were the most frequent (10\%), followed by cancers of the hematopoietic and lymphatic organs (8.09\%). However, Ando et al. [19] present that chondrosarcoma is the second most common type of primary bone tumor in adults after osteosarcoma. Chondrosarcoma, represented the fourth with $7.5 \%$ of cases, $58.82 \%$ of which affected the age group of 0 - 24 years. However, according to the literature, they are exceptional in children since only $3.8 \%$ of chondrosarcomas occur before age 20 [19].

Ewing's tumor represents only $1.8 \%$ of the cases in our series. This low incidence is in agreement with the literature [19] which emphasizes that Ewing's tumor appears to be 9 times more common in white skin subjects compared to black skin subjects even if, apart from this, there is no factor favoring the occurrence was clearly incriminated.

Finally in ourseries the histological types in the upperlimb and pelvis were mainly sarcomas and lymphomas; (Table 1) makingthen a singularity.

\section{Conclusions}

Primary bone cancers are rare in Ivory Coast. At the end of this work, the profile of PMBT in Ivory Coast is that of a male child, from a socio-economic background who consults for maxillofacial tumefaction or lower limb evolving in a chronic mode. The clinical picture was dominated by pain and alteration of the general state. Radiology is quite variable depending on the histological type.

Burkitt's lymphoma and osteosarcoma are the often diagnosed histological types they most often affect male children with maxillofacial involvement and 
predominant lower extremity.

\section{Conflict of Interests}

The authors declare that they have no competing interests.

\section{Author's Contributions}

All the authors contributed of the writing of this manuscript and have read and approved the final version.

\section{References}

[1] Fletcher, C.D., Unni, K.K. and Mertens, F. (Eds.) (2002) Pathology and Genetics of Tumours of Soft Tissue and Bone (Vol. 4). IARC, Lyon.

[2] Steliarova-Foucher, E., Stiller, C., Lacour, B. and Kaatsch, P. (2005) International Classification of Childhood Cancer. Cancer, 103, 1457-1467.

https://doi.org/10.1002/cncr.20910

[3] Hawkins, D.S., Rajendran, J.G., Conrad, E.U., Bruckner, J.D. and Eary, J.F. (2002) Evaluation of Chemotherapy Response in Pediatric Bone Sarcomas by [F-18] -fluorodeoxy-D-glucose Positron Emission Tomography. Cancer, 94, 3277-3284. https://doi.org/10.1002/cncr.10599

[4] Diomandé, I., D’Horpock, A.F., Heroin, P., et al. (1988) Évolution des cancers en Côte-d'Ivoire. Revint sc méd-RISM, 75, 81-84.

[5] Echimane, A., Ahnoux, A., Adoubi, I., et al. (2000) Cancer Incidence in Abidjan, Ivory Coast. First Results from the Cancer Registry, 1995-1997. Cancer, 89, 653-663. https://doi.org/10.1002/1097-0142(20000801)89:3<653::AID-CNCR22>3.0.CO;2-Z

[6] Jemal, A., Siegel, R., Tiwari, C., et al. (2004) Cancer Statistics 2004. CA: A Cancer Journal for Clinicians, 54, 8. https://doi.org/10.3322/canjclin.54.1.8

[7] Kouakou N'zue, M., Akonde-Comoe, M.L., Eti, E., et al. (1994) Métastasesosseusesen milieu hospitalier Ivoirien: à propos de 26 cas. Rhumatologie, 46, 243-245.

[8] Daboiko, J.C., Eti, E., Yapi, I., Ouali, B., Ouattara, B. and N'zué, K. (2004) Inflammatory Rheumatic Diseases at Co-Cody University Medical Center (Abidjan) from March 1998 to March 2000. Joint Bone Spine, 71, 598-599. https://doi.org/10.1016/j.jbspin.2004.04.011

[9] Atchi, W., Yaovi, J.E., Koami, A., Anani, A., Michel, D.A., Faré, G.P. and Gamal, A. (2015) les tumeurs osseuses primitives des membres au chu tokoin de lomeprimary bone tumors of members in tokointeachinghospital of lome. European Scientific Journal, 11, No. 27.

[10] Eyre, R., Feltbower, R.G., Mubwandarikwa, E., Eden, T.O. and McNally, R.J. (2009) Epidemiology of Bone Tumours in Children and Young Adults. Pediatric Blood \& Cancer, 53, 941-952. https://doi.org/10.1002/pbc.22194

[11] Omololu, A.B., Ogunbivi, J.O., Ogunlade, S.O., et al. (2002) Primary Malignant Bone Tumors in a Tropical African University Teaching Hospital. West African Journal of Medicine, 21, 291-293.

[12] Bahebeck, J., Atangana, R., Eyenga, V., Pisoh, A., Sando, Z. and Hoffmeyer, P. (2003) Bone Tumours in Cameroon: Incidence, Demography and Histopathology. International Orthopaedics, 27, 315-317. https://doi.org/10.1007/s00264-003-0480-7

[13] Ibrahima, F., Motah, M., Nonga, B.N., Singwe, M.N., et al. (2013) Prise en charge des tumeurs osseuses au Cameroun. Notre expérience initiale. Health Sciences and 
Diseases, 12, No. 2.

[14] Bana, A., Lambin, Y., Agoh, S., Kouassi, J.C. and Varango, G. (2000) Les tumeurs osseuses primitives a propos de 50 cas observés au chu de cocody. Rev Int Sce Med, 2, 15-24.

[15] Triffaud, A., Mazabraud, A. and Jasmin, C. (1980) Les sarcomes osteogenes. Editions Scientifiques et Médicales Elsevier SAS, Paris, 1430, D10.

[16] Effi, A.B., Aman, N.A., Koffi, K.D., et al. (2012) Cancers solides de l'enfant en Côte d'Ivoire: étude de 556 cas. Journal Africain du Cancer, 4, 204-208.

https://doi.org/10.1007/s12558-012-0222-4

[17] Kakpovi, K., Houzou, P., EyramFianyo, M.K., Koffi-Tessio, V.E., Tagbor, K.C., Oniankitan, O. and Mijiyawa, M. (2016) Profile of Malignant Bone Tumors among Rheumatology Inpatients in Lome (Togo). Open Journal of Rheumatology and Autoimmune Diseases, 6, 51-56. https://doi.org/10.4236/ojra.2016.63009

[18] Oniankitan, O., Houzou, P., Kakpovi, K., et al. (2009) Rheumatic Diseases Profile of 13517 West African Patients. Tunisie Médicale, 91, 16-20.

[19] d'Andon, A., Vassal, P.G., Oberlin, O. and Hartmann, O. (2004) Les tumeurs osseuses. Institut Gustave Roussy, Villejuif.

[20] Weber, K., Damron, T.A., Frassica, F.J. and Sim, F.H. (2008) Malignant Bones Tumors. Instructional Course Lectures, 57, 673-688.

[21] Baena-Ocampo, C., Atangana, R., Eyenga, V., Pisoh, A., Sandoz, Z. and Hoffmeyer, P. (2009) Epidemiology of Bones Tumors in Mexico City: Retrospective Clinicopathologic Study of 566 Patients at a Referral Institution. Annals of Diagnostic Pathology, 13, 16-21. https://doi.org/10.1016/j.anndiagpath.2008.07.005

[22] Yeole, B.B. and Jussawalla, D.J. (1998) Descriptive Epidemiology of Bone Cancer in Greater Bombay. Indian Journal Cancer, 35, 101-106.

[23] Abdulkareem, F.B., Evesan, S.U., Akinde, O.R., et al. (2007) Pathological Studies of Bone Tumors at the National Orthopaedic Hospital. West African Journal of Medicine, 26, 306-311.

[24] Segbena, A. (1997) Le lymphome de Burkitt au Togo: Aspect épidémiologique, clinique, thérapeutique et évolutif. Medecine d'Afrique Noire, 44, 141-145.

[25] Meangui, L. (1999) Tumeurs solides malignes de l'enfant. Etude épidémiologique et histopathologique à propos de 237 cas. Doctoral Dissertation, Thèse méd, Abidjan.

[26] Gadegbeku, S., Koutouan, A., et al. (1988) La maladie de Burkitt en Cóte d'Ivoire. Rev. Sto. Chir. Max. Fac, 87, 201-211.

[27] Burkitt, D.P. and O'Connor, G.T. (1961) Malignant Lymphoma in Africa Children. I. A Clinical Syndrome. Cancer, 14, 258-269. https://doi.org/10.1002/1097-0142(196103/04)14:2<258::AID-CNCR2820140206>3. $\underline{0 . \mathrm{CO} ; 2-7}$

[28] Cantaloube, D., Bellavoir, A., Rives, J.M. and Pasturel, A. Stomatologie Tropicale: lymphome de Burkitt Africain, pian, noma, lèpre. Encycl. Med. Chir. (Paris), Stomatologie 22050T10, 2-1990, 14 p. 